Document downloaded from:

http://hdl.handle.net/10251/49587

This paper must be cited as:

Dalmau Borrás, A.; Guiñón Pina, V.; Devesa Albeza, F.; Amigó Borrás, V.; Igual Muñoz, AN. (2015). Electrochemical behavior of near-beta titanium biomedical alloys in phosphate buffer saline solution. Materials Science and Engineering: C. 48:55-62. doi:10.1016/j.msec.2014.11.036.

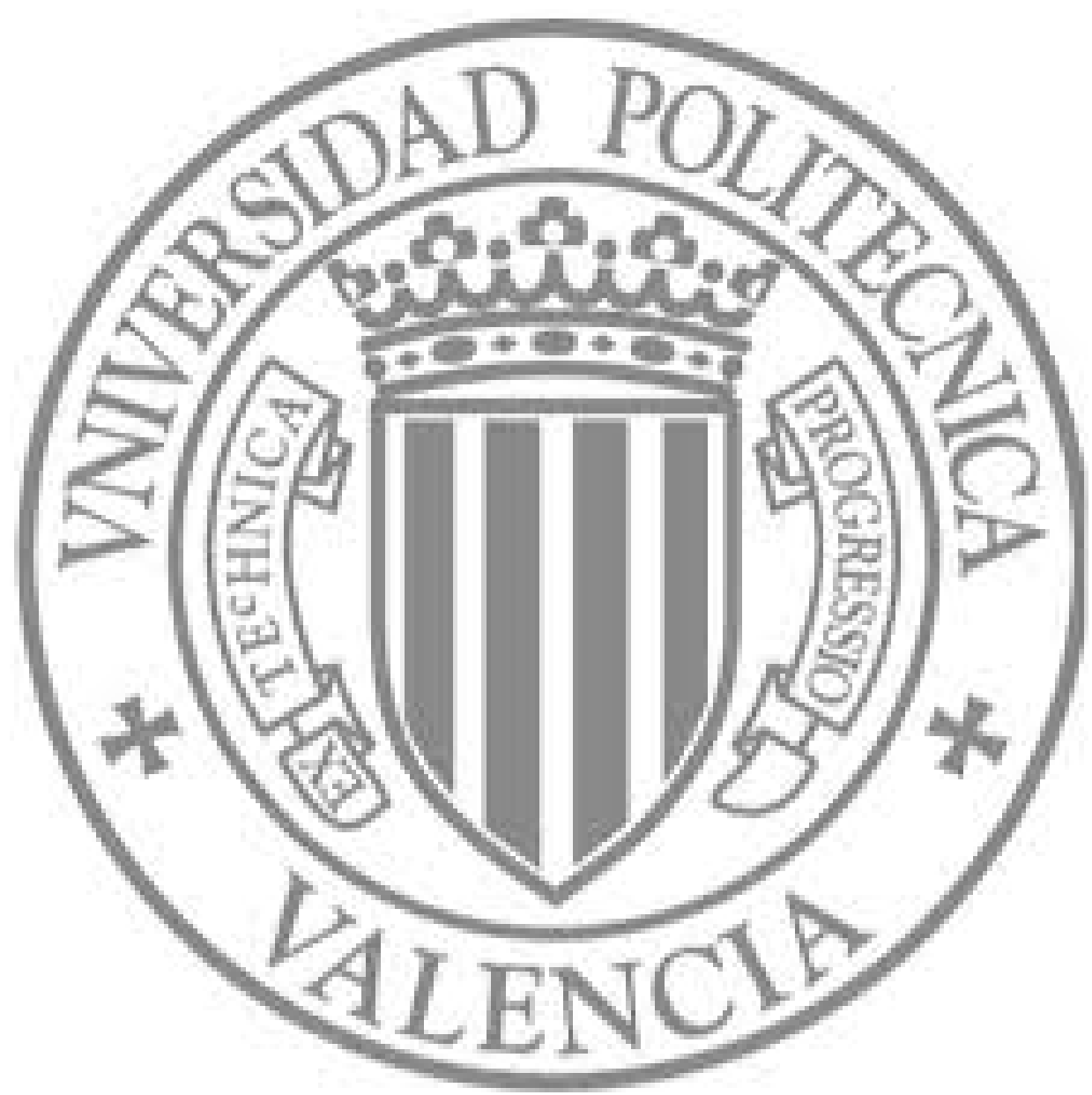

The final publication is available at

http://dx.doi.org/10.1016/j.msec.2014.11.036

Copyright Elsevier 


\title{
Electrochemical behaviour of near-beta titanium biomedical alloys in phosphate buffer saline solution
}

\author{
A. Dalmau ${ }^{1 \text { * }}$, V. Guiñón Pina ${ }^{1)}$, F. Devesa ${ }^{2)}$, V. Amigó ${ }^{2)}$, A. Igual Muñoz ${ }^{1)}$ \\ 1) Institute for Industrial, Radiophysical and Environmental Safety, Universidad Politécnica de Valencia, \\ P.O. BOX 22012, E-46071, Valencia, Spain \\ 2) Institute of Materials Technology, Universidad Politécnica de Valencia, P.O. BOX 22012, E-46071, \\ Valencia, Spain \\ *Corresponding author: aldalbor@posgrado.upv.es
}

\begin{abstract}
The electrochemical behaviour of three different near- $\beta$ titanium alloys (composed by $\mathrm{Ti}, \mathrm{Nb}$ and $\mathrm{Sn}$ ) obtained by powder metallurgy for biomedical applications has been investigated. Different electrochemical and microscopy techniques were used to study the influence of the chemical composition ( $\mathrm{Sn}$ content) and the applied potential on the microstructure and the corrosion mechanisms of those titanium alloys. Addition of Sn below 4\% wt. to the titanium powder improves the microstructural homogeneity and generates an alloy with high corrosion resistance with low elastic modulus, being more suitable as a biomaterial. When the Sn content is above $4 \%$, the corrosion resistance considerably decreases by increasing the passive dissolution rate; this effect is enhanced with the applied potential.
\end{abstract}

Keywords: near- $\beta$ titanium alloys; passivation; biomaterials; corrosion; electrochemical impedance spectroscopy (EIS). 


\section{Introduction}

The use of titanium and its alloys in the biomedical field have increased considerably due to their excellent properties: low density, high hardness, good corrosion resistance, inactivity with the biological environment, low elastic modulus and high capacity to attach to tissue and bone, making titanium a good choice as a biomaterial [1][2]. Pure titanium is an allotropic element, which can form more than one crystal structure. At low temperatures, the titanium forms an $\alpha$ phase with hexagonal closed-packed (HCP) structure. Above $882.5^{\circ} \mathrm{C}$ it is transformed into a $\beta$ phase with body centre cubic (BCC) structure. The $\alpha$ to $\beta$ phase transformation temperature ( $\beta$ transus) can be raised or lowered depending on the alloying elements and their content. Some elements, aluminium or oxygen, stabilize the $\alpha$ phase and raise the $\beta$ transus temperature, while other elements, vanadium, molybdenum or niobium, stabilize the $\beta$ structure and lower the $\beta$ transus [3]. Some other elements, tin and zirconium, behave neutrally at low and moderate concentrations. According to the concentration of the alloying elements and the phases present at room temperature, titanium alloys are classified as $\alpha, \alpha+\beta$ and $\beta$ alloys. Commercially pure titanium ( $\alpha$ alloy) and the Ti6Al4V alloy ( $\alpha+\beta$ alloy) were found to be the most employed alloys for dental implants during years, although they exhibit prolonged use limitations: high elastic modulus compared to the bone, and low wear resistance [4],6]. Ti6Al4V was also found to be toxic due to the release of aluminium and vanadium ions [6]. Recent effort has been focused on developing new titanium alloys specifically for biomedical applications [7] such as the $\beta$ alloys. The $\beta$ microstructure has good specific properties, because of their low density, excellent corrosion resistance [8] and low elastic modulus compared with $\alpha$ and $\alpha+\beta$ titanium alloys.

The corrosion behaviour of titanium alloys depends on an oxide film formation mainly composed of $\mathrm{TiO}_{2}$, which spontaneously covers the titanium surface and its alloys in presence of oxygen [6]. The chemical properties of the oxide layer play an important role in the biocompatibility of titanium implants and the surrounding tissues. The corrosion behaviour of $\beta$ Ti alloys is governed by the $\beta$ stabilizing elements. These $\mathrm{Ti}$ alloys form a single compact layer that contains $\mathrm{TiO}_{2}$ and traces of other oxides. The presence of niobium in the alloy enhances its passivation by decreasing the concentration of the anion vacancies in the $\mathrm{TiO}_{2}$ film [6]. Therefore, TiNb alloys show superior corrosion resistance when compared to the traditional Ti6Al4V [9]. TiNbSn alloys have a uniform surface corrosion which provides a passive film which can be formed by $\mathrm{Ti}_{2} \mathrm{O}_{3}, \mathrm{TiO}_{2}, \mathrm{Nb}_{2} \mathrm{O}_{5}$ and $\mathrm{SnO}_{2}[12,13]$. Several studies have demonstrated that TiNbSn alloys have lower Young's modulus than the Ti alloys which reduces the stress shielding phenomena [3,4,14]. Kuroda et al. compared TiNbTaSn alloys [5], showing that the alloy containing $2 \%$ wt. of Sn (Ti29Nb13Ta2Sn) had the lowest Young's modulus, compared to the same alloy containing 4.6 and $6 \%$ of $\mathrm{Sn}$. It has also been observed that the tensile strength of the TiNbSn alloy is higher than that of the Ti6Al4V [12].

In order to meet the demands of longer human life and implantation in younger patients, the development of novel metallic alloys for biomedical applications is a requirement nowadays. The most promising alloys for implant application are $\beta$-type titanium alloys composed of non-toxic elements. Many $\beta$-type alloys composed by $\mathrm{Nb}$, $\mathrm{Ta}, \mathrm{Zr}, \mathrm{Mo}, \mathrm{Hf}, \mathrm{Au}, \mathrm{Pd}, \mathrm{Pt}, \mathrm{Ag}, \mathrm{Ga}, \mathrm{Ge}, \mathrm{Sc}$ and $\mathrm{Sn}$ were developed in the last two decades [13]. One recently developed promising biomedical alloy, Ti3Zr2Sn3Mo25 Nb shows significant improvement of the corrosion resistance and biocompatibility 
compared to previous generation of Ti alloys such as CP Ti and Ti6Al4V [14]. Liu et al. [15] studied the in vitro effects of some alloying elements, including the Sn on pure iron and they obtained that there was not significant cytotoxicity to ECV304 cells, except for the FeMn alloy. Wan et al. also studied the biocompatibility of Ti35Nb2.5Sn and Ti35Nb1.4Sn alloys [16], revealing that osteoblasts cells have good growing and spreading ability on the surface of $\mathrm{Ti} 35 \mathrm{NbxSn}$ and that cell viability for the $\mathrm{Ti} 35 \mathrm{Nb} 2.5 \mathrm{Sn}$ is 0.4 times higher than for $\mathrm{CP} \mathrm{Ti}$.

By conventional powder metallurgy elemental powders are mixed and good final properties of the alloy, such tensile stresses, specific strength and a good combination of toughness and fatigue resistance are obtained despite of the inherent porosity of the process $[15,16]$. It avoids the remelting of the material and subsequent heat treatments performed in the fusion process [19]. Nowadays porous titanium has become a popular surgical implant material since it increases the roughness and the porosity of the material, thus increasing the integration of the material device to the bone [18-20]. As the roughness increases the osseointegration is greater, but the active surface is also higher promoting the corrosion and the formation of oxides on the titanium surface $[16,21,22]$. An homogeneous microstructure is achieved even though all the diffusion process is conducted in solid state [9]. On the contrary, Sn helps to the titaniumniobium diffusion spread as it has a relatively low melting point and form a liquid phase in the sintering phase [23][18]. Regarding the phase diagrams of $\mathrm{Ti}-\mathrm{Nb}$ alloys, it is necessary a minimum of $25 \%$ at. $\mathrm{Nb}$ to have a $\beta$ alloy [24]. When other elements are added, the quantification of the $\beta$ phase can be estimated using the molybdenum equivalent [25]. In the present study, the titanium alloys contain $30 \% \mathrm{wt}$. of $\mathrm{Nb}$, which corresponds to $18 \%$ at. or 9 equivalent molybdenum. In the case of an amount of $\beta$ phase up to the $80 \%$, some authors name this type of alloys as "near- $\beta$ " [26][27][28].

The aim of this work is to metallographically and electrochemically characterize new near- $\beta$ alloys composed by $\mathrm{Ti}, \mathrm{Nb}$ and $\mathrm{Sn}$ obtained by powder metallurgy for biomedical applications.

\section{Experimental}

\subsection{Fabrication process of the samples}

Three titanium alloys have been studied: Ti-30Nb, Ti-30Nb-2Sn and Ti-30Nb$4 \mathrm{Sn}$, where the numbers indicate the weight percentage of the alloying elements $\mathrm{Nb}$ and Sn respectively. These alloys have been obtained by blending elemental powders. The titanium powders obtained by hidruded - deshidruded (HDH) technique were provided by Sejong Materials Co. LTD. Niobium and tin powders have been provided by Alfa Aesar and Pometon Spain S.A. respectively. Tin and niobium powders have been screened to obtain particle size below 25 microns in order to facilitate the diffusion processes of these elements and to obtain a more homogeneous microstructure. The compaction of the samples was carried out in an automatic press applying uniaxial pressure of $400 \mathrm{MPa}$. Rectangular die of $12 \times 30 \mathrm{~mm}$ has been used. A floating rate matrix has been used to decrease the stress gradient between the upper and the lower side of the specimen. The final specimens are cylindrical bars of $26 \mathrm{~mm}$ in diameter and $6 \mathrm{~mm}$ thick. 
Sintering has been carried out in a furnace Carbolite model 15/75/450de HVT under high vacuum conditions $\left(<10^{-4}\right.$ bar $)$, because the high reactivity of titanium. The sintering cycle starts from room temperature up to $800^{\circ} \mathrm{C}$ at a heating rate of $15^{\circ} \mathrm{C} / \mathrm{min}$. This temperature is kept constant for 30 minutes to homogenize the temperature throughout the furnace, avoid cracking problems and prepare the allotropic change of titanium $\left(\alpha \rightarrow \beta 882^{\circ} \mathrm{C}\right)$. Then temperature is raised up to $1250{ }^{\circ} \mathrm{C}$, which is the sintering temperature, at a rate of $10{ }^{\circ} \mathrm{C} / \mathrm{min}$. The sintering time is 2 hours. Finally, temperature decreases at room temperature at $15^{\circ} \mathrm{C} / \mathrm{min}$.

\subsection{Metallographic study}

Specimens were wet-ground with 220 to 4000 grit silicon carbide (SiC) paper and further polished with OP-Chem polishing clothes using the OP-S colloidal silica suspension to a mirror like finishing. Porosity and equivalent diameter of the pores were obtained using an optical microscopy NIKON LV100. The grain size has been revealed by etching the samples with Kroll reagent ( $3 \mathrm{ml} \mathrm{HF}, 6 \mathrm{ml} \mathrm{HNO}_{3}, 100 \mathrm{ml} \mathrm{H}_{2} \mathrm{O}$ ) and analysing the attacked surface through a light microscopy. The microstructure of the alloys has been observed by optical and scanning electron microscopy (SEM) in a JEOL JSM 6300. Alloys have been also observed by transmission electron microscopy (TEM) with a Philips microscopy $\mathrm{CH} 10$. The samples for TEM observation were prepared through ion milling cooled with liquid nitrogen at cryogenic temperatures in order to minimize artifacts in the selected area. The microstructural phases were investigated on the inner surfaces of the specimens by means of X-ray diffraction (XRD). The XRD studies were performed using a Philips X'pert diffractometer with $\mathrm{CuKa}$ radiation $(\lambda=$ $0.15406 \mathrm{~nm}$ ) and XRD patterns were collected in the $2 \Theta$ ranges from 20 to $90^{\circ}$ and they were analyzed with the X'Pert Plus software (PANalytical).

\subsection{Electrochemical tests.}

Prior to the tests, the samples were cleaned in an ultrasonic bath with acetone and ethanol for 5 minutes respectively in order to remove any existing particle from the pores. The samples were not polished and had a roughness of $R_{a}=2.4 \mu \mathrm{m}$. Only the upper surface of the samples $\left(1.13 \mathrm{~cm}^{2}\right)$ was exposed to the electrolyte and the lower part was insulated and electrically connected to the potentiostat.

Electrochemical tests were conducted in a phosphate buffered solution (PBS) with the composition of $8 \mathrm{~g} / \mathrm{L} \mathrm{NaCl}, 0.2 \mathrm{~g} / \mathrm{L} \mathrm{KCl}, 1.44 \mathrm{~g} / \mathrm{L} \mathrm{Na} \mathrm{HPO}_{4}$ and $0.25 \mathrm{~g} / \mathrm{L}$ $\mathrm{KH}_{2} \mathrm{PO}_{4}$. All chemicals were of analytical grade and doubly distilled water was employed in the preparation of the solutions. Temperature of the solution was kept at $37^{\circ} \mathrm{C}$.

Measurements were carried out using an Autolab 302N. The three-electrode electrochemical setup included a platinum wire as counter electrode and a $\mathrm{Ag} / \mathrm{AgCl}$ $(3 \mathrm{M} \mathrm{KCl})$ as reference electrode. All potentials were referred to the reference electrode (0.205 V versus standard hydrogen electrode, SHE).

Open circuit potential (OCP) was measured for one hour at the beginning of the tests. The corrosion behaviour was investigated using potentiodynamic curves carried out from -1.1 $\mathrm{V}_{\mathrm{Ag} / \mathrm{AgCl}}$ to $3 \mathrm{~V}_{\mathrm{Ag} / \mathrm{AgCl}}$ at a scan rate of $0.5 \mathrm{mV} / \mathrm{s}$. The following 
electrochemical parameters were obtained from the anodic polarization curves: the corrosion potential $\left(\mathrm{E}_{\text {corr }}\right)$ and the corrosion current density $\left(\mathrm{i}_{\text {corr }}\right)$ determined by the Tafel slope extrapolation and the passive current density $\left(i_{p}\right)$, where the current density remains approximately constant corresponding to the passive zone.

Potentiostatic measurements were carried out at different applied potentials: 0, 1 and $2 \mathrm{~V}_{\mathrm{Ag} / \mathrm{AgCl}}$. Parameters obtained from potentiostatic tests are the passivation current density $\left(\mathrm{i}_{\mathrm{pp}}\right)$ and the electrochemical charge $(\mathrm{Q})$.

Electrochemical impedance spectroscopy (EIS) measurements were carried out under potentiostatic conditions at the constant passive potentials of 0,1 and $2 \mathrm{~V}_{\mathrm{Ag} / \mathrm{AgCl}}$. Impedance measurements were performed from $2 \mathrm{mHz}$ to $10^{4} \mathrm{~Hz}$ with an amplitude of the sinusoidal wave of $10 \mathrm{mV}$. The impedance data were analysed with the ZView 2.70 software package and fitted to the corresponding equivalent circuit.

All tests were repeated twice to check for reproducibility.

\section{Results}

\subsection{Microstructure and surface characterization}

The microstructure of the Ti30NbxSn alloys is shown in Figure 1 and Figure 2. The optical images of the etched surfaces in Figure 1 show the small black dots which correspond to the existing porosity as a result of the manufacturing process. This porosity is much higher in case of Ti30Nb (Figure 1a), decreasing when $\mathrm{Sn}$ is added (Figure $1 \mathrm{~b}$ and $1 \mathrm{c}$ ).

Figure 2 shows the micrographs of the Ti30Nb alloy obtained by SEM and TEM. A predominantly $\beta$ microstructure with a lamellar $\alpha$ structure which grows from the grain boundaries is observed in Figure 2a. Furthermore, it appears a lack of homogeneity in the composition caused by the low diffusion, especially of $\mathrm{Nb}$ : lighter areas are rich in $\mathrm{Nb}$ while darker areas are rich in Ti. Sintered alloys with $\mathrm{Sn}$, Ti30Nb2Sn and Ti30Nb4Sn, present higher homogeneity which confirms that Sn forms a liquid phase during sintering, improving significantly the diffusion process. Moreover, a higher Sn content implies a lower $\alpha$ zone because $\mathrm{Nb}$ diffuses better into Ti. The $\alpha+\beta$ zone has been observed by TEM, Figure $2 b$, where it is shown a $\beta$ and an $\alpha+\beta$ grain.

The X-ray diffraction results, shown in Figure 3, reveal evidence of a $\beta$ microstructure with some regions of $\alpha$ phase nucleation. As there was a slow cooling process and there have not been performed heat treatments in the samples, other phase precipitations, such as as $\alpha^{\prime}, \alpha^{\prime \prime}$ or $\omega$, were not detected. Similar results were obtained by Aleixo et al. [29] where they analysed the microstructure and phases formed during cooling of $\beta$ TiNbSn alloy through different cooling rates and, from their results, the faster cooling rate shows higher amount of precipitation phases. 

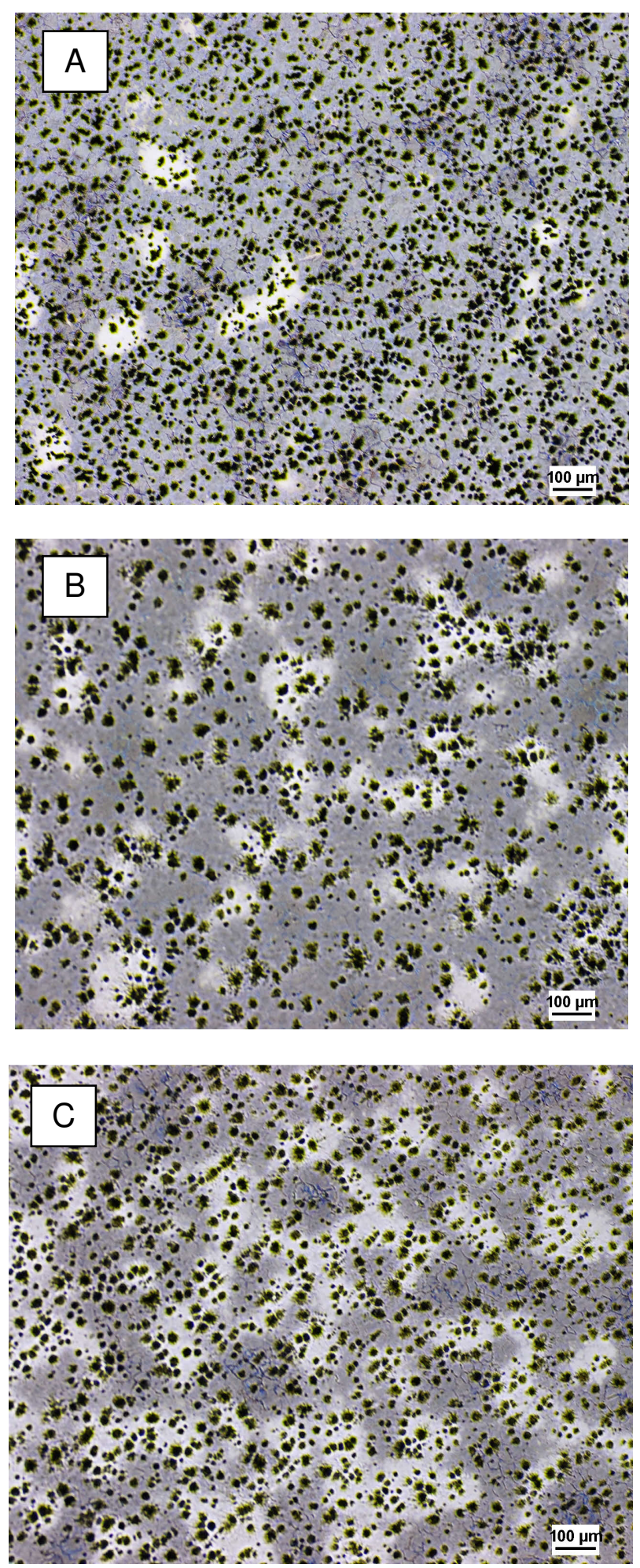

Figure 1. Optical images of etched A) Ti30Nb, B) Ti30Nb2Sn and C) Ti30Nb4Sn alloys, x50. 

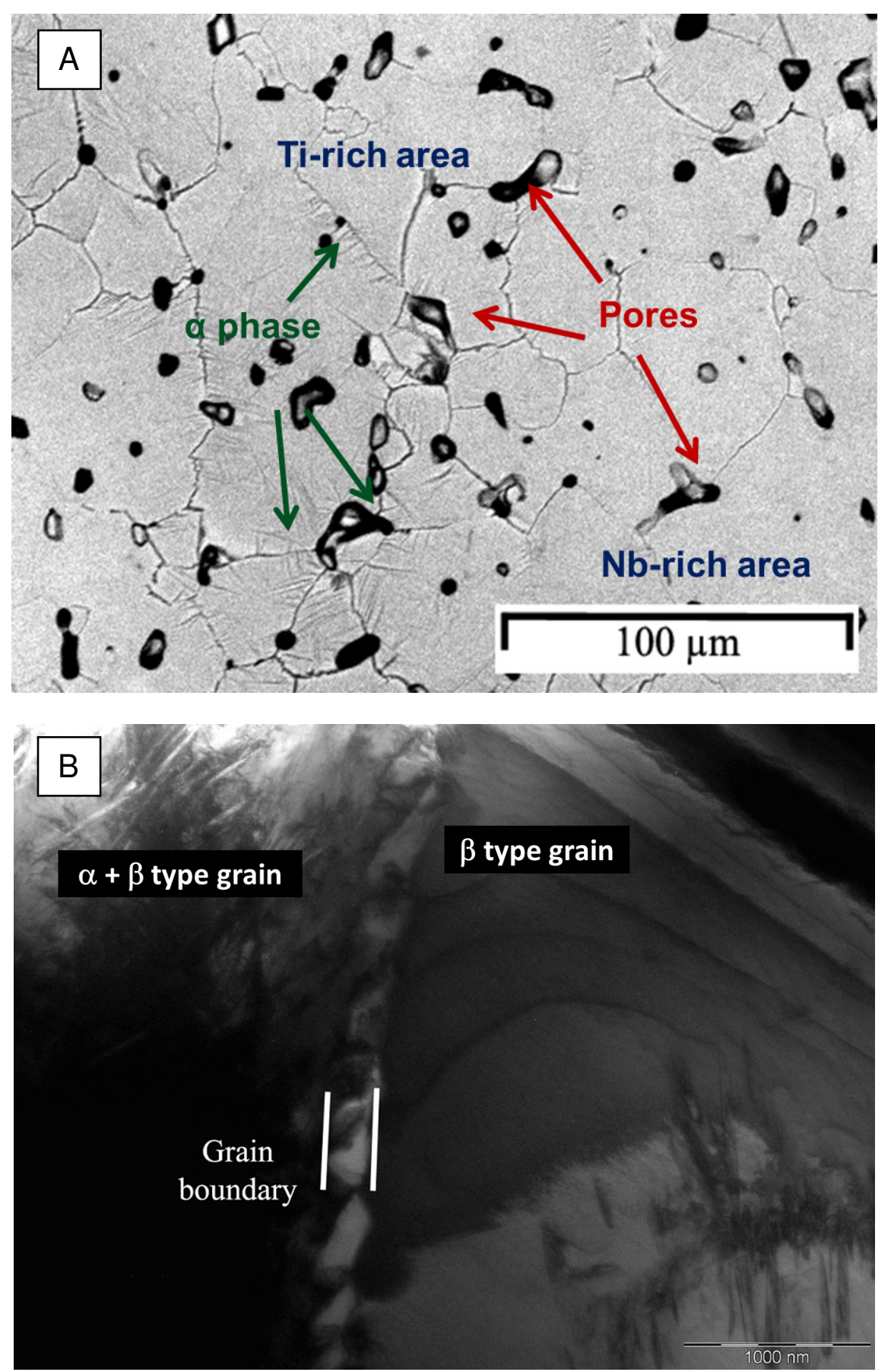

Figure 2. A) SEM and B) TEM micrographs of the etched Ti30Nb at x500 and x5200, respectively. 


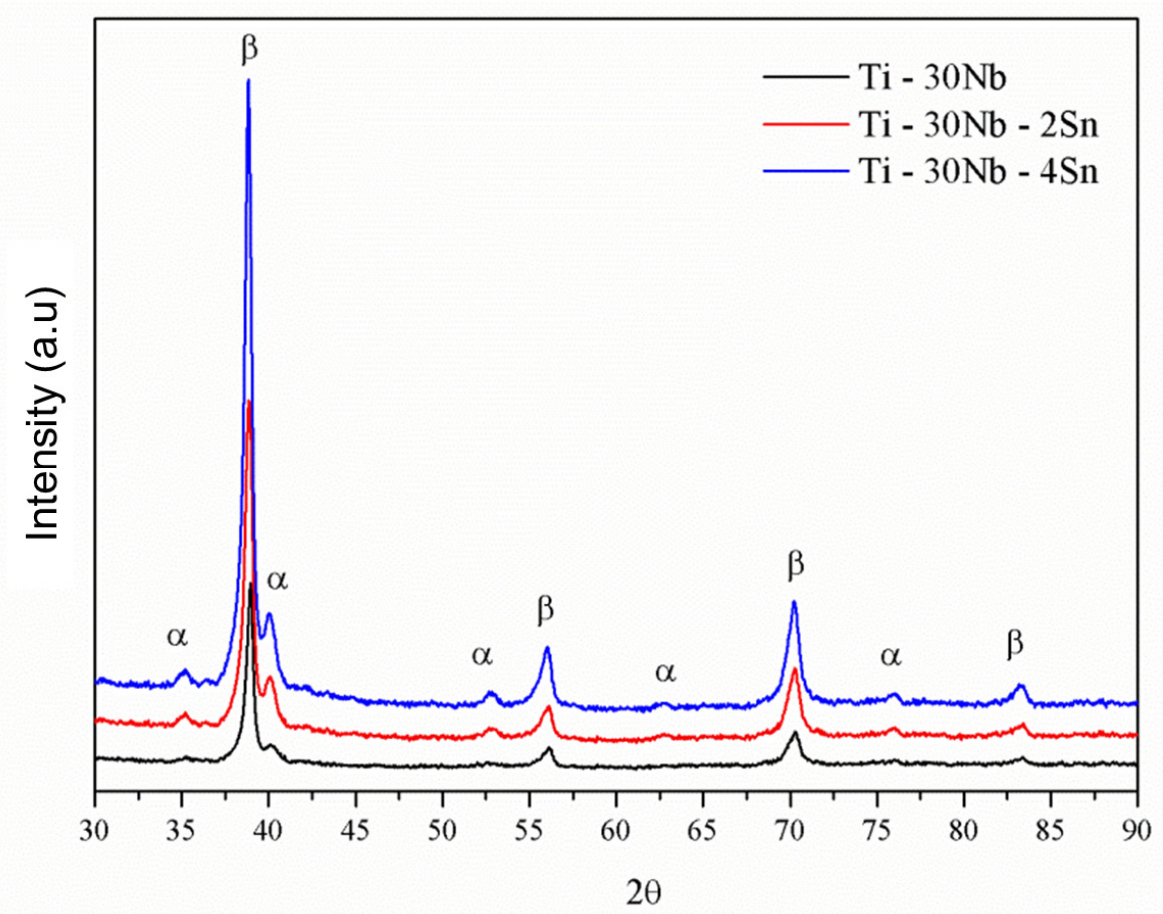

Figure 3. X-ray diffraction patterns of the surface of the different Ti30NbxSn studied alloys.

Table 1 shows the porosity values (\%), the equivalent diameter of the pores, the active area of the alloy and the grain size of the studied alloys. The porosity decreases when $\mathrm{Sn}$ is added, in good agreement with the images of Figure 1.

The active area was calculated by means of the porosity and the equivalent diameter, assuming that the surface of a pore corresponds to half a sphere:

$$
S_{e s f / 2}=\frac{4 \pi r^{2}}{2}=2 \pi r^{2}
$$

Where $\mathrm{r}$ is the radius of the pore. According to the small differences in the equivalent diameter of the pore of the different alloys, very similar active area are obtained, Table 1. Considering the nominal area of $1.13 \mathrm{~cm}^{2}$, we can calculate the increase in the active area caused by the porosity, which is $11.5,6.2$ and $7.3 \%$ for the $\mathrm{Ti} 30 \mathrm{Nb}, \mathrm{Ti} 30 \mathrm{Nb} 2 \mathrm{Sn}$ and Ti30Nb4Sn respectively. There is no influence of the Sn content on the grain size.

Table 1. Surface characterization of the Ti30Nb-xSn alloys.

\begin{tabular}{ccccc}
\hline Alloy & $\begin{array}{c}\text { Porosity } \\
(\boldsymbol{\%})\end{array}$ & $\begin{array}{c}\text { Equivalent diameter } \\
\text { of pore }(\boldsymbol{\mu m})\end{array}$ & $\begin{array}{c}\text { Active area } \\
\left(\mathbf{c m}^{\mathbf{2}}\right)\end{array}$ & $\begin{array}{c}\text { Grain Size } \\
(\boldsymbol{\mu m})\end{array}$ \\
\hline Ti30Nb & $13.23 \pm 0.52$ & $11.5 \pm 0.80$ & $1.28 \pm 0.01$ & $29.62 \pm 1.09$ \\
Ti30Nb2Sn & $6.56 \pm 0.49$ & $12.5 \pm 0.80$ & $1.20 \pm 0.08$ & $31.92 \pm 0.99$ \\
Ti30Nb4Sn & $7.82 \pm 1.39$ & $10.9 \pm 0.70$ & $1.22 \pm 0.04$ & $29.38 \pm 0.77$ \\
\hline
\end{tabular}




\subsection{Electrochemical characterization}

\subsubsection{DC tests}

Figure 4 shows the polarization curves of the titanium alloys in the PBS solution. The electrochemical parameters extracted from them are summarised in Table 2, including the OCP values obtained before the polarization curves. The parameters are referred to the real active area, Table 1.

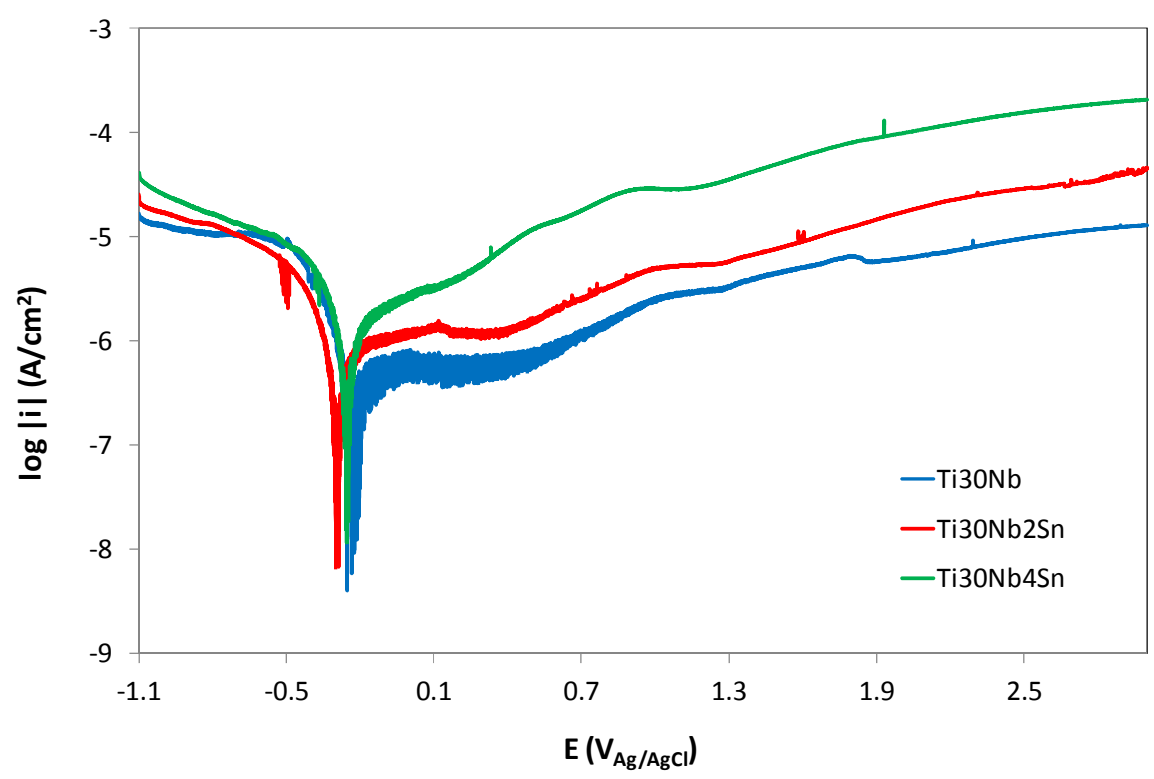

Figure 4. Potentiodynamic curves of Ti30Nb, Ti30Nb2Sn and Ti30nb4Sn in PBS at $37^{\circ} \mathrm{C}$

Four different domains are observed in the potentiodynamic curves of all samples. The cathodic domain includes potentials below the corrosion potential where the current is determined by the reduction of water and partially of dissolved oxygen. The domain comprised between $-0.35 \mathrm{~V}_{\mathrm{Ag} / \mathrm{AgCl}}$ and $-0.12 \mathrm{~V}_{\mathrm{Ag} / \mathrm{AgCl}}$ is characterized by the transition from cathodic to anodic current at the corrosion potential. A large passive zone was found between the $\mathrm{E}_{\mathrm{corr}}$ and $0.6 \mathrm{~V}_{\mathrm{Ag} / \mathrm{AgCl}}$ where the current density remained approximately constant, except for the Ti30Nb4Sn. In this domain, the passive film impedes the dissolution of the metal and reduces the corrosion rate. Finally, a transpassive domain is observed. The current density increases with the applied potential, due to the oxidation of water and oxides of the passive film. Main differences between alloys are observed in the passive and transpassive domains, where the current densities increase with the Sn content. 
Table 2. Electrochemical parameters of the titanium alloys in PBS at $37^{\circ} \mathrm{C}$.

\begin{tabular}{lcccc}
\hline & OCP & $\mathbf{E}_{\text {corr }}$ & $\mathbf{i}_{\text {corr }}\left(\boldsymbol{\mu A} \mathbf{A} / \mathbf{c m}^{2}\right)$ & $\begin{array}{c}\mathbf{i}_{\mathbf{p}} \\
\left(\boldsymbol{\mu A} \mathbf{A} / \mathbf{c m}^{2}\right)\end{array}$ \\
\hline Ti30Nb & $-0.007 \pm 0.05$ & $-0.222 \pm 0.013$ & $0.075 \pm 0.003$ & $0.591 \pm 0.04$ \\
Ti30Nb2Sn & $-0.135 \pm 0.09$ & $-0.292 \pm 0.004$ & $0.120 \pm 0.056$ & $0.712 \pm 0.48$ \\
Ti30Nb4Sn & $0.007 \pm 0.13$ & $-0.247 \pm 0.010$ & $0.406 \pm 0.304$ & $4.500 \pm 4.24$ \\
\hline
\end{tabular}

The lowest values of OCP and $\mathrm{E}_{\text {corr }}$ were reached by the Ti30Nb2Sn, while the highest current densities were observed in the Ti30Nb4Sn. OCP and $\mathrm{E}_{\text {corr }}$ do not follow a trend with the $S n$ content, while $S n$ content increases $i_{\text {corr }}$ and $i_{p}$. OCP values show higher scatter than the $\mathrm{E}_{\text {corr }}$ ones.

Figure 5 shows the evolution of the current density with time at $0 \mathrm{~V}_{\mathrm{Ag} / \mathrm{AgCl}}$ (a), $1 \mathrm{~V}_{\mathrm{Ag} / \mathrm{AgCl}}$ (b) and $2 \mathrm{~V}_{\mathrm{Ag} / \mathrm{AgCl}}$ (c) of all the titanium alloys. In all cases an exponential decay in the current with time was observed as the metal passivates due to the oxide film formation and growth. The passivation current density $\left(i_{\mathrm{pp}}\right)$ is a quantitative measure of the passive dissolution rate and it increases with the applied potential in all cases. The charge $(\mathrm{Q})$ is proportional to the dissolved cations and it also increases with the applied potential. Table 3 summarizes the charge $(\mathrm{Q})$ and the passivation current density $\left(\mathrm{i}_{\mathrm{pp}}\right.$ ) values obtained from the potentiostatic test of Figure 5; both, $\mathrm{i}_{\mathrm{pp}}$ and $\mathrm{Q}$ values of $\mathrm{Ti} 30 \mathrm{Nb}$ and $\mathrm{Ti} 30 \mathrm{Nb} 2 \mathrm{Sn}$ are very similar while Ti30Nb4Sn shows the highest values of all the studied parameters, thus presenting the highest passive dissolution rate. This is in good agreement with the previous potentiodynamic tests, Figure 4. 
a

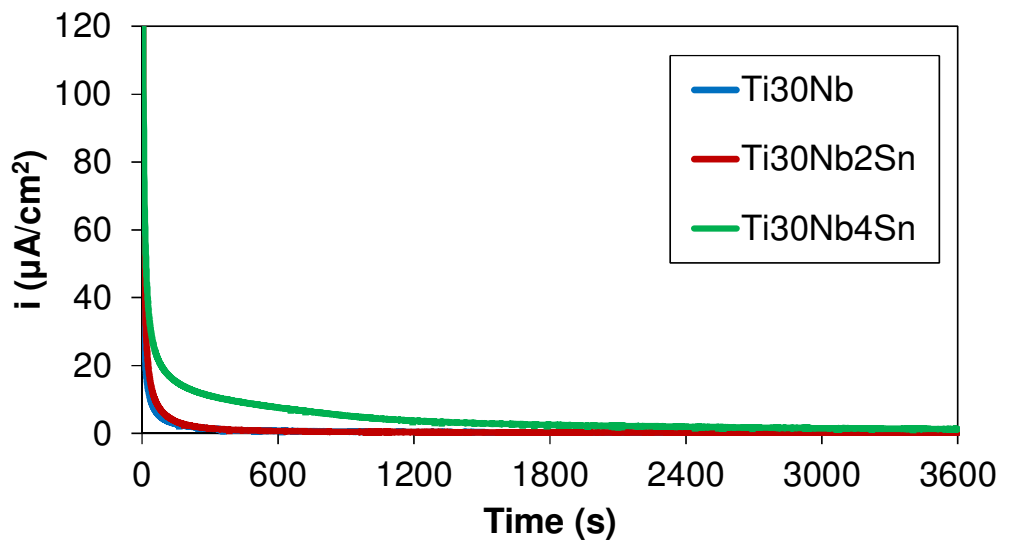

b

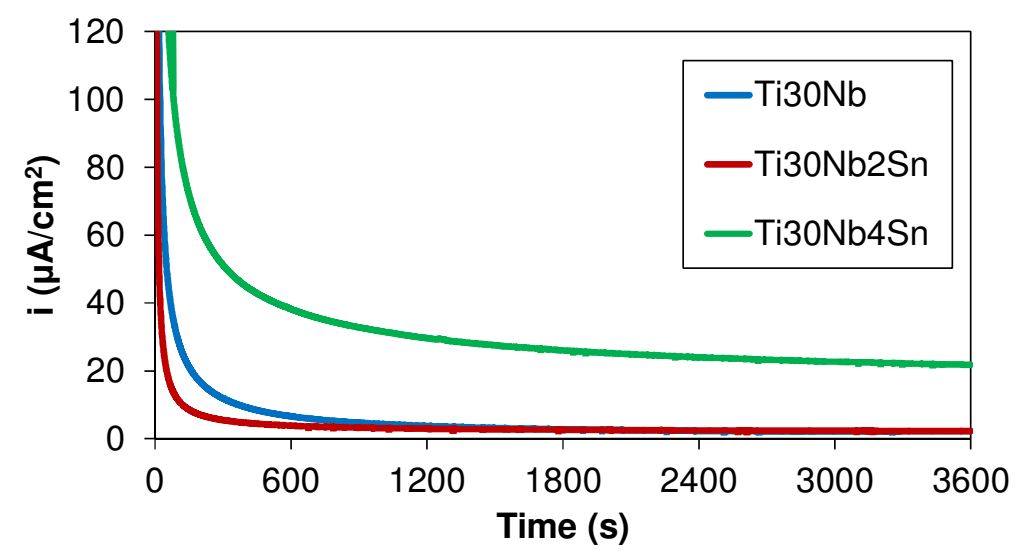

c

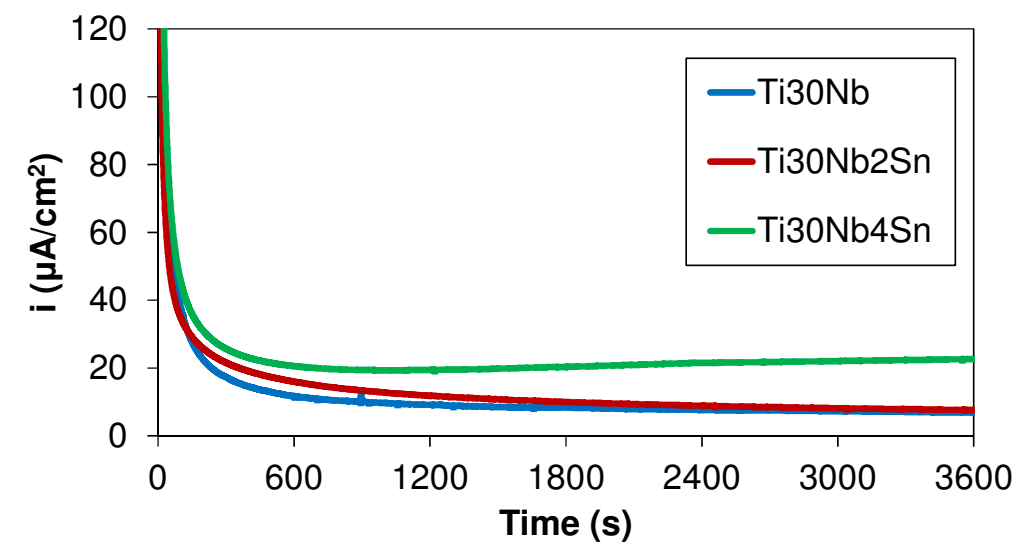

Figure 5. Potentiostatic curves of Ti30Nb, Ti30Nb2Sn and Ti30nb4Sn in PBS at $37^{\circ} \mathrm{C}$ at $0 \mathrm{~V}_{\mathrm{Ag} / \mathrm{AgCl}}(\mathrm{a}), 1 \mathrm{~V}_{\mathrm{Ag} / \mathrm{AgCl}}$ (b) and $2 \mathrm{~V}_{\mathrm{Ag} / \mathrm{AgCl}}$ (c). 
Table 3. $Q$ and $i_{\mathrm{pp}}$ values of the titanium alloys in $\mathrm{PBS}$ at $37^{\circ} \mathrm{C}$ at $0 \mathrm{~V}_{\mathrm{Ag} / \mathrm{AgCl},} 1 \mathrm{~V}_{\mathrm{Ag} / \mathrm{AgCl}}$ and $2 \mathrm{~V}_{\mathrm{Ag} / \mathrm{AgCl}}$.

\begin{tabular}{|c|c|c|c|c|c|c|}
\hline & \multicolumn{2}{|c|}{$0 \mathrm{~V}_{\mathrm{Ag} / \mathrm{AgCl}}$} & \multicolumn{2}{|c|}{$1 \mathrm{~V}_{\mathrm{Ag} / \mathrm{AgCl}}$} & \multicolumn{2}{|c|}{$2 \mathrm{~V}_{\mathrm{Ag} / \mathrm{AgCl}}$} \\
\hline & $\begin{array}{c}\mathbf{i}_{\mathbf{p p}} \\
\left(\boldsymbol{\mu} \mathbf{A} / \mathbf{c m}^{2}\right)\end{array}$ & $\begin{array}{c}\mathbf{Q} \\
\left(\mathrm{mC} / \mathrm{cm}^{2}\right)\end{array}$ & $\begin{array}{c}\mathbf{i}_{\mathrm{pp}} \\
\left(\boldsymbol{\mu} \mathrm{A} / \mathbf{c m}^{2}\right)\end{array}$ & $\begin{array}{c}\mathbf{Q} \\
\left(\mathrm{mC}^{2} \mathrm{~cm}^{2}\right)\end{array}$ & $\begin{array}{c}\mathbf{i}_{\mathrm{pp}} \\
\left(\boldsymbol{\mu} \mathrm{A} / \mathbf{c m}^{2}\right)\end{array}$ & $\begin{array}{c}\mathbf{Q} \\
\left(\mathrm{mC}^{2} \mathrm{~cm}^{2}\right)\end{array}$ \\
\hline Ti30Nb & $0.06 \pm 0.04$ & $2.32 \pm 0.35$ & $1.71 \pm 0.72$ & $17.69 \pm 7.71$ & $6.86 \pm 1.21$ & $30.72 \pm 4.35$ \\
\hline Ti30Nb2Sn & $0.23 \pm 0.14$ & $3.86 \pm 0.34$ & $1.49 \pm 1.24$ & $12.59 \pm 6.83$ & $7.63 \pm 0.92$ & $33.83 \pm 7.21$ \\
\hline Ti30Nb4Sn & $1.00 \pm 0.23$ & $11.66 \pm 5.10$ & $14.85 \pm 9.82$ & $67.94 \pm 18.30$ & $21.66 \pm 1.40$ & $128.68 \pm 11.72$ \\
\hline
\end{tabular}

\subsubsection{AC tests}

Figure 6 shows the impedance spectra (Nyquist and Bode plots) for the titanium alloys in PBS at the different applied anodic potentials, 0,1 and $2 \mathrm{~V}_{\mathrm{Ag} / \mathrm{AgCl}}$. Two time constants can be distinguished in the impedance spectra according to the broad phase angle maxima observed in the Bode plots. In order to interpret the electrochemical behaviour of the Ti30 Nb-xSn alloys, an equivalent electrical circuit (EEC) is used to model the experimental data. Solid lines in Figure 6 correspond to the fitted model. The EEC data is shown in Figure 7 and consists of two RC circuits in parallel. This circuit was already proposed by different authors [12,21,24,25]. One time constant is attributed to the charge transfer resistance $\left(\mathrm{R}_{\mathrm{ct}}\right) /$ double layer capacitance $\left(\mathrm{C}_{\mathrm{dl}}\right)$ parallel combination, and the second is attributed to the film resistance $\left(\mathrm{R}_{\text {film }}\right) /$ film capacitance $\left(\mathrm{C}_{\text {film }}\right)$ parallel combination. The fitted values are shown in Table 4.

The theoretical simulated impedance parameters for the tested alloys were computed and summarized in Table 5. The criteria used in estimating the quality of the fit are evaluated with the lower chi-square $\left(\chi^{2}\right)$, values around $10^{-4}[30]$.

A constant phase angle element (CPE) is introduced to replace the capacitor and to account for the non-ideal behaviour of the capacitive elements due to different physical phenomena such as surface heterogeneity which results from surface roughness, impurities, dislocations or grain boundaries. These inhomogenities are present on a microscopic level under the oxide phase and at the oxide/electrolyte interface. CPE is defined in impedance representation as:

$$
Z(\omega)=Z_{0} \cdot(i \omega)^{-n}
$$

Where $Z_{0}$ is the CPE constant, $\omega$ is the angular frequency in $\mathrm{rad} / \mathrm{s}, \mathrm{i}^{2}=-1$ is the imaginary number and $\mathrm{n}$ is the CPE exponent.

Therefore, the double layer capacitance $\left(\mathrm{C}_{\mathrm{dl}}\right)$ and film capacitance $\left(\mathrm{C}_{\text {film }}\right)$ are given by the following equations [31]:

$$
\begin{gathered}
C_{\mathrm{dl}}=\left(\frac{\mathrm{CPE}_{\mathrm{dl}}}{\left(\mathrm{R}_{\mathrm{s}}^{-1}+\mathrm{R}_{\mathrm{ct}}{ }^{-1}\right)^{1-\mathrm{n}_{\mathrm{dl}}}}\right)^{1 / \mathrm{n}_{\mathrm{dl}}} \\
\mathrm{C}_{\mathrm{film}}=\left(\frac{\mathrm{CPE}_{\mathrm{film}}}{\left(\left(\mathrm{R}_{\mathrm{s}}+\mathrm{R}_{\mathrm{ct}}\right)^{-1}+\mathrm{R}_{\mathrm{film}}{ }^{-1}\right)^{1-\mathrm{n}_{\mathrm{film}}}}\right)^{1 / \mathrm{n}_{\mathrm{film}}}
\end{gathered}
$$


And the polarization resistance $\left(R_{p}\right)$ is given by the sum of the charge transfer resistance $\left(R_{c t}\right)$ and the film resistance $\left(R_{\text {film }}\right)$ as follows:

$$
R_{p}=R_{c t}+R_{\text {film }}
$$

$\mathbf{a}$

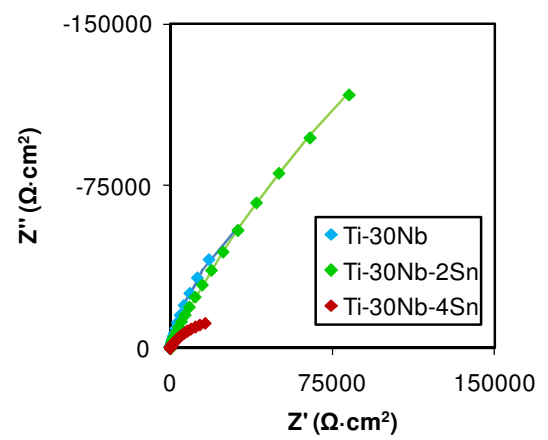

b

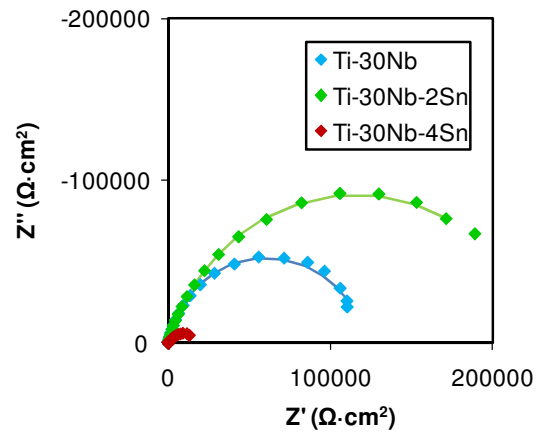

c

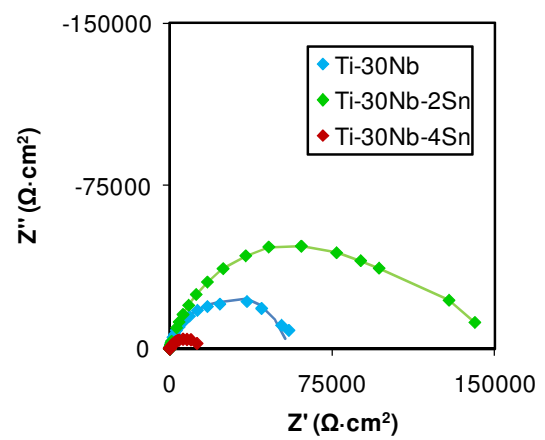

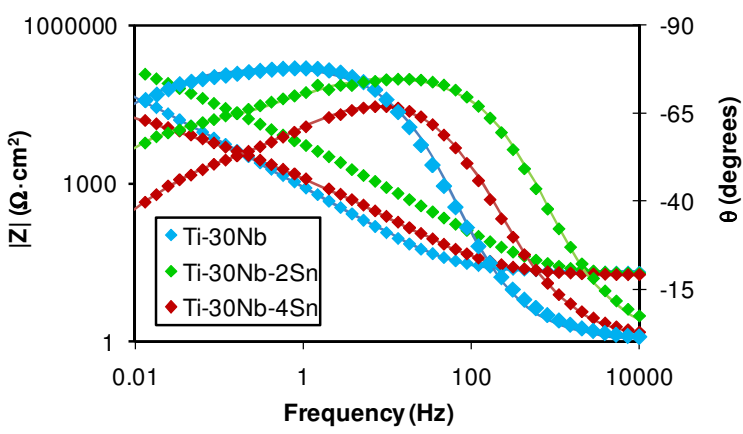
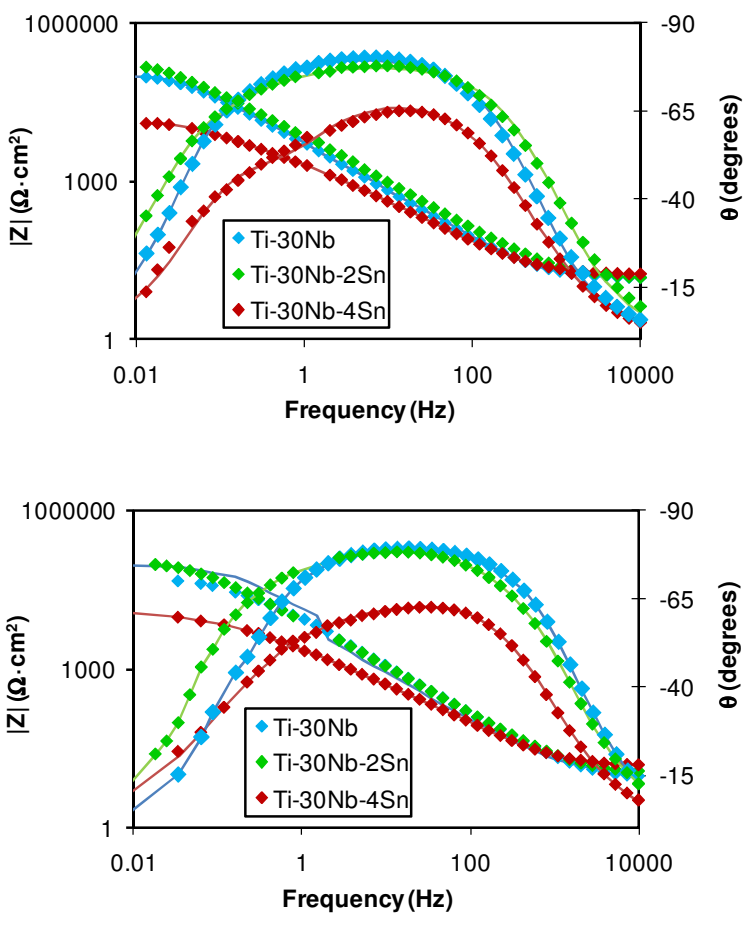

Figure 6. Nyquist diagrams (left) and Bode plots (right) of Ti30Nb, Ti30Nb2Sn and Ti30Nb4Sn alloys after $1 \mathrm{~h}$ of immersion at (a) $0 \mathrm{~V}_{\mathrm{Ag} / \mathrm{AgCl}}$, (b) $1 \mathrm{~V}_{\mathrm{Ag} / \mathrm{AgCl}}$ and (c) $2 \mathrm{~V}_{\mathrm{Ag} / \mathrm{AgCl}}$ in $\mathrm{PBS}$ at $37^{\circ} \mathrm{C}$. 


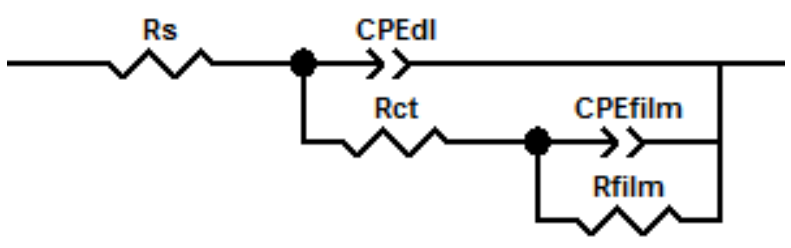

Figure 7. Equivalent electrical circuit for the analysis of the impedance spectra. $R_{\mathrm{s}}$ is the solution resistance, $R_{c t}$ is the charge transference resistance, $R_{f i l m}$ is the film resistance, $\mathrm{CPE}_{\mathrm{dl}}$ is the $\mathrm{CPE}$ of the double layer resistance and $\mathrm{CPE}_{\text {film }}$ is the $\mathrm{CPE}$ of the film.

Table 4. Electrochemical parameters at different potentials of Ti30Nb-xSn alloys in $\mathrm{PBS}$ at $37^{\circ} \mathrm{C}$.

\begin{tabular}{|c|c|c|c|c|c|c|c|c|c|c|}
\hline & $\begin{array}{c}\mathbf{R}_{\mathrm{s}} \\
\left(\boldsymbol{\Omega} \cdot \mathbf{c m}^{2}\right)\end{array}$ & $\begin{array}{c}\mathbf{C P E}_{\mathrm{dl}} \\
\left(\mu \mathrm{F} / \mathrm{cm}^{2}\right)\end{array}$ & $\mathbf{n}_{\mathrm{dl}}$ & $\begin{array}{c}\mathbf{R}_{\mathrm{ct}} \\
\left(\mathrm{k} \boldsymbol{\Omega} \cdot \mathrm{cm}^{2}\right)\end{array}$ & $\begin{array}{c}\mathrm{C}_{\mathrm{dl}} \\
\left(\mu \mathrm{F} / \mathbf{c m}^{2}\right)\end{array}$ & $\begin{array}{c}\mathrm{CPE}_{\text {film }} \\
\left(\mu \mathrm{F} / \mathrm{cm}^{2}\right)\end{array}$ & $\mathbf{n}_{\text {film }}$ & $\begin{array}{c}\mathbf{R}_{\text {film }} \\
\left(\mathbf{k} \boldsymbol{\Omega} \cdot \mathrm{cm}^{2}\right)\end{array}$ & $\begin{array}{c}\mathrm{C}_{\text {film }} \\
\left(\mu \mathrm{F} / \mathrm{cm}^{2}\right)\end{array}$ & $\begin{array}{c}\mathbf{R}_{\mathbf{p}} \\
\left(\mathbf{k} \boldsymbol{\Omega} \cdot \mathrm{cm}^{2}\right)\end{array}$ \\
\hline & \multicolumn{10}{|c|}{$0 \mathrm{~V}_{\mathrm{Ag} / \mathrm{AgCl}}$} \\
\hline Ti30Nb & 19 & 262 & 0.92 & 118 & 165.2 & 39 & 0.65 & 1200 & 84.4 & 1318 \\
\hline Ti30Nb2Sn & 17 & 39 & 0.86 & 113 & 11.8 & 21 & 0.51 & 2000 & 45.7 & 2113 \\
\hline \multirow[t]{2}{*}{ Ti30Nb4Sn } & 16 & 163 & 0.82 & 3 & 44.1 & 195 & 0.55 & 41 & 119.2 & 44 \\
\hline & \multicolumn{3}{|c|}{$1 \mathrm{~V}_{\mathrm{Ag} / \mathrm{AgCl}}$} & & & & & & & \\
\hline Ti30Nb & 15 & 36 & 0.91 & 63 & 17.1 & 20 & 0.30 & 300 & 22.0 & 363 \\
\hline Ti30Nb2Sn & 15 & 32 & 0.88 & 71 & 11.3 & 16 & 0.20 & 500 & 15.7 & 571 \\
\hline \multirow[t]{2}{*}{ Ti30Nb4Sn } & 16 & 135 & 0.74 & 10 & 16.6 & 110 & 0.25 & 13 & 26.5 & 23 \\
\hline & \multicolumn{3}{|c|}{$2 \mathrm{~V}_{\mathrm{Ag} / \mathrm{AgCl}}$} & & & & & & & \\
\hline Ti30Nb & 11 & 14 & 0.89 & 80 & 4.7 & 2 & 0.30 & 90 & 0.01 & 170 \\
\hline Ti30Nb2Sn & 11 & 31 & 0.85 & 83 & 7.6 & 2 & 0.30 & 110 & 0.01 & 193 \\
\hline Ti30Nb4Sn & 15 & 61 & 0.77 & 1 & 7.5 & 57 & 0.40 & 16 & 0.72 & 17 \\
\hline
\end{tabular}

In all cases, $\mathrm{R}_{\text {film }}$ is higher than $\mathrm{R}_{\mathrm{ct}}$ and $\mathrm{n}_{\mathrm{dl}}$ higher than $\mathrm{n}_{\text {film }}$. This is not surprising since the passive film exercises more resistance than the charge transfer against metal dissolution, and the film behaviour is not ideal. However the Ti30Nb4Sn alloy shows the highest differences between $\mathrm{R}_{\mathrm{ct}}$ and $\mathrm{R}_{\mathrm{film}}$. Capacitance and resistance values of the passive film decrease with the applied potential. At all applied potentials, Ti30Nb2Sn presents the highest $R_{p}$ value and the lowest $C_{\text {film }}$ value, being the alloy more resistant to corrosion under the studied conditions. There is no significant difference in $\mathrm{C}_{\mathrm{dl}}$ between all the studied alloys, except at $0 \mathrm{~V}_{\mathrm{Ag} / \mathrm{AgCl}}$ where the Ti30 Nb alloy shows a very high value. Ti30Nb4Sn alloy presents very high values of capacitance and very low values of resistance, showing the lowest corrosion resistance under the studied conditions. 


\section{Discussion}

Better diffusion titanium-niobium occurs when alloying with Sn, Figure 1, obtaining a more homogenous distribution of the alloying elements. Wang et al. [32] also observed that the $\beta$ phase becomes more stable with the $\mathrm{Sn}$ content. It also contributes to the decrease of the porosity, Table 1, and decreases the young modulus $[5,6,14]$. However, the effect of Sn on the corrosion properties depends on the Sn content in the alloy. Adding $2 \%$ of $\mathrm{Sn}$ to the $\mathrm{Ti} 30 \mathrm{Nb}$ alloy provides slightly higher corrosion resistance but increasing the amount to $4 \%$ Sn content reduces their passive resistance (decrease in $R_{p}$ and increase in $i_{p p}$ ).

According to literature, current density during passivation is generated by two different processes: growth of the oxide film and passive dissolution. Therefore the total measured current $\left(i_{p p}\right)$ can be divided into a growth and a corrosion contribution [2730]:

$$
i_{p p}=i_{\text {growth }}+i_{\text {diss }}
$$

where $i_{\text {diss }}$ is the amount of current proportional to the metal dissolution and $\mathrm{i}_{\text {growth }}$ corresponds to the amount of current used for the formation of the passive oxide film. Figure 8 shows a diagram of the two processes taking place at the oxide film/electrolyte interface and at the metal/oxide interface respectively considering that $\mathrm{Ti}^{4+}$ and $\mathrm{Nb}^{5+}$ dissolution is negligible when compared to $\mathrm{Sn}^{4+}$ dissolution [30-32]. The growth current density ( $i_{\text {growth }}$ ) was assumed to be controlled by an interface equilibrium and the total current density $\left(\mathrm{i}_{\mathrm{pp}}\right)$ was assumed to be limited by the potential drop in the film according to the High Field Model (HFM) [34].

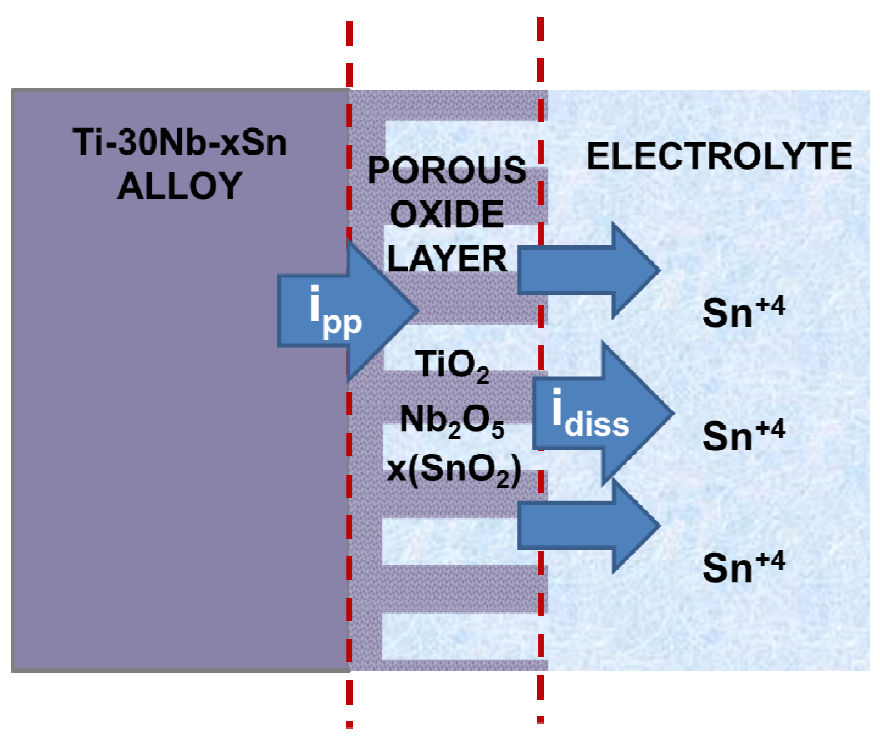

Figure 8. Scheme of the passive film formation, adapted from [33].

As the content of $\mathrm{Sn}$ increases in the alloy, the value of the passivation current density also increases at all the applied potentials, Figure 9. Passive dissolution rate is significantly higher when the concentration of $\mathrm{Sn}$ in the alloy is above $2 \%$. At potentials above $0 \mathrm{~V}_{\mathrm{Ag} / \mathrm{AgCl}}$ this dissolution rate is even accelerated because the electrochemical conditions are above the reversible potential for $\mathrm{Sn}\left(\mathrm{E}_{\mathrm{Sn}+4 / \mathrm{Sn}+2}=-0.05 \mathrm{~V}_{\mathrm{Ag} / \mathrm{AgCl}}\right)$. 
Although $\mathrm{Sn}$ contributes to the better $\mathrm{Ti}-\mathrm{Nb}$ diffusion, thus to the homogeneity of the alloy, it also increases the passive dissolution rate above a critical content ( $2 \%$ in the studied case).

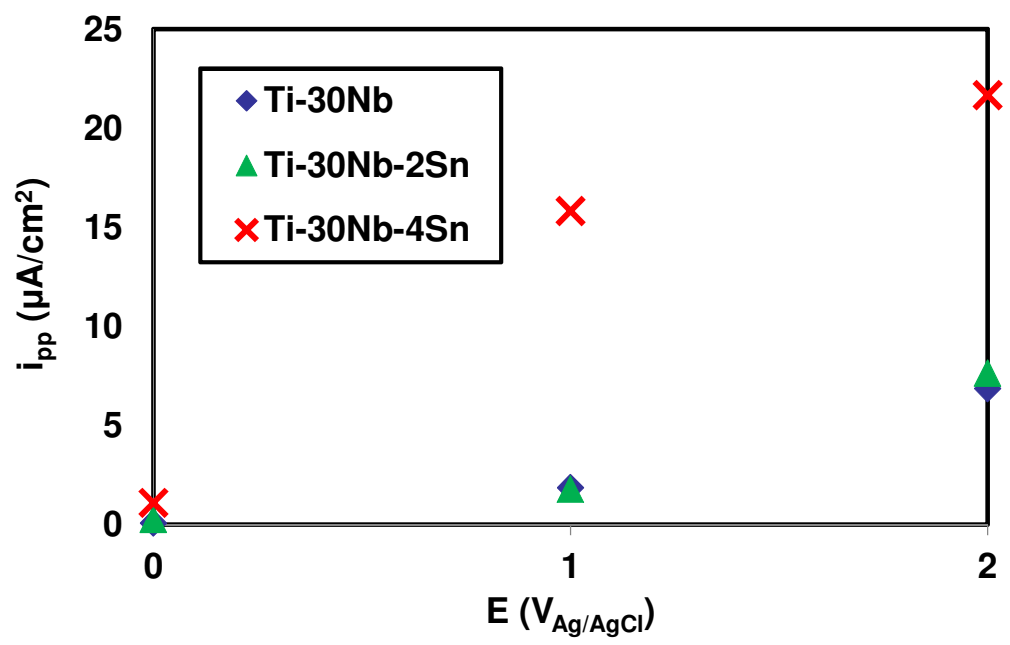

Figure 9. Representation of passivation current density versus potential for Ti30NbxSn alloys.

The polarization resistance $\left(\mathrm{R}_{\mathrm{p}}\right)$ represents the resistance to the passive dissolution and therefore it is inversely proportional to $\mathrm{i}_{\mathrm{pp}}$. According to the HFM, a low value of $R_{p}$ and a high value of $i_{p p}$ implies that most of the metallic cations dissolve into the electrolyte instead of contributing to the growth of the passive film. Figure 10a presents the inverse of the $R_{p}$ in function of the $i_{p p}$. Ti30Nb and Ti30Nb2Sn show low $i_{p p}$ values at all applied potentials and lower $1 / R_{p}$ values (high $R_{p}$ ) when compared to Ti30Nb4Sn. Therefore when $\mathrm{Sn}$ in the alloy is below $2 \%$, the corrosion behaviour is dominated by the passive film formation.

It has been reported that the capacitance of the film $\left(\mathrm{C}_{\mathrm{film}}\right)$ is related to the quality and the thickness of the passive film [31-34]. Figure 10b shows the relation between $\mathrm{C}_{\text {film }}$ and $\mathrm{i}_{\mathrm{pp}}$ of the different alloys at the studied potentials. In all cases there is a decrease in the $\mathrm{C}_{\text {film }}$ with the increase in $\mathrm{i}_{\mathrm{pp}}$. However the trend depends on the alloy. For the Ti30Nb and Ti30Nb2Sn the increase in $i_{p p}$ with the decrease in $\mathrm{C}_{\text {film }}$ is due to a thickening of the passive film. This is in a good agreement with the results obtained by Milosev et al. $[35,36]$ who studied the evolution of the chemical composition and the thickness of the passive films of $\beta \mathrm{Ti}$ alloys with the potential. They observed an increase in the thickness of the passive film of TiAlNb and TiNbZrTa alloys with the applied potential. They also concluded that the incorporation of oxides of alloying elements into the $\mathrm{TiO}_{2}$ layer increased the corrosion resistance of the alloys. This is confirmed in the Ti30Nb2Sn which showed higher resistances and lower capacitance values than the Ti30Nb. In the Ti30Nb4Sn, the only thickening of the passive film cannot explain the high increase in $\mathrm{i}_{\mathrm{pp}}$. Therefore, the decrease in $\mathrm{C}_{\text {film }}$ is also caused by the migration of the $\mathrm{Sn}^{+4}$ through the passive film, which in terms causes an increase of $\mathrm{i}_{\mathrm{pp}}$. 

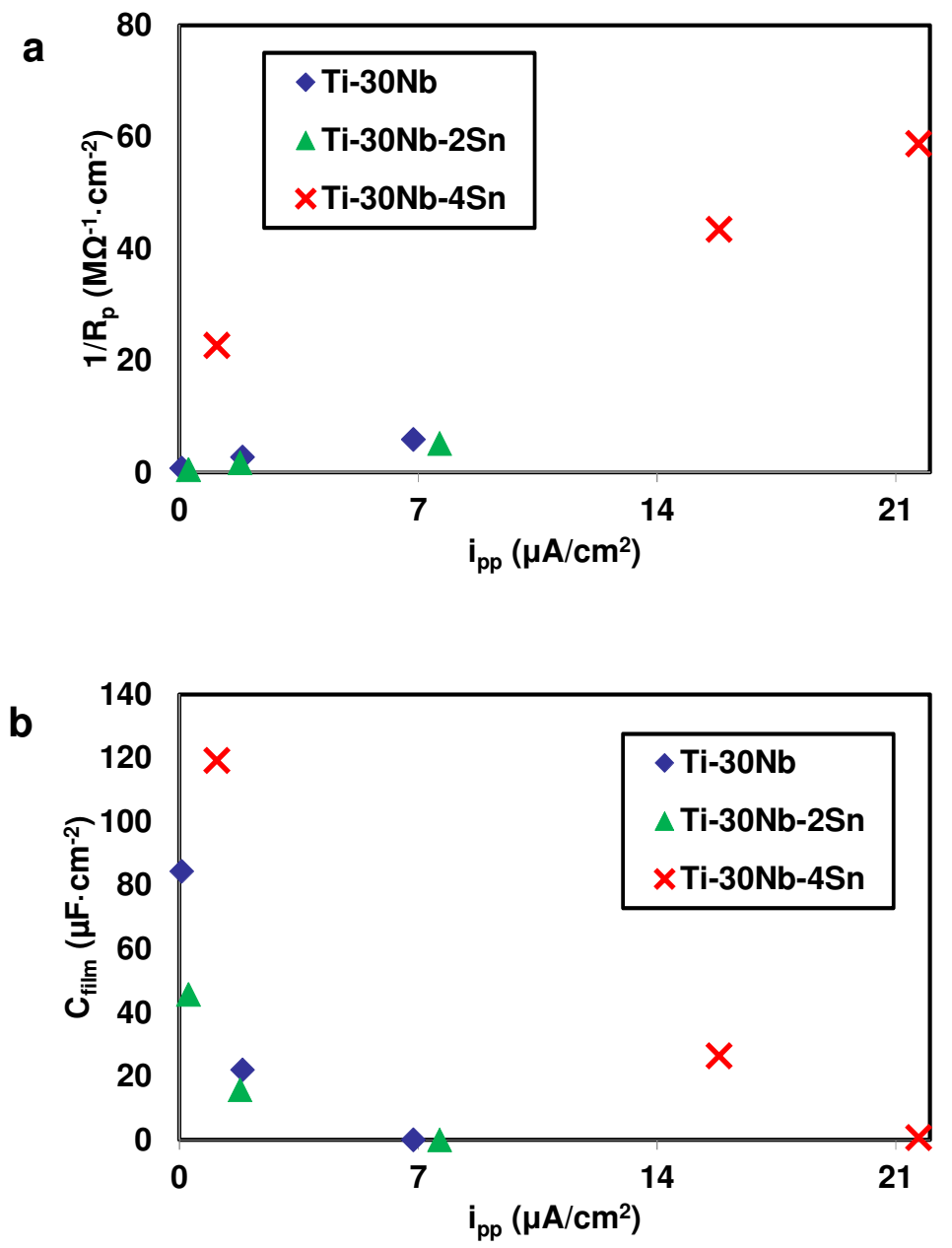

Figure 10. Representation of the inverse of the polarization resistance (a) and capacitance of the passive film (b) versus the passivation current density for the Ti30Nb-xSn alloys.

\section{Conclusions}

The following conclusions can be drawn from the microstructural and electrochemical study of three different $\beta$ titanium alloys obtained by powder metallurgy.

The microstructure and the alloying elements have an important influence on the electrochemical behaviour of the titanium alloys. Adding a small amount of $\mathrm{Sn}(2 \% \mathrm{wt}$.) to a $\mathrm{Ti} 30 \mathrm{Nb}$ alloy generates a more homogeneous microstructure, because the $\mathrm{Sn}$ facilitates the titanium-niobium diffusion. The addition of Sn also decreases the porosity of the alloys. The elastic modulus also decreases with the $\mathrm{Sn}$ addition. This Sn amount also causes a better corrosion resistance of the Ti30Nb2Sn when compared to the $\mathrm{Ti} 30 \mathrm{Nb}$ one. However, when the Sn content in the alloys is above $4 \%$ wt. (in the Ti30Nb4Sn alloy) an enhancement of the passive dissolution was obtained. 
The effect on $\mathrm{Sn}$ addition on the passive dissolution is potential dependent, thus increasing when the potential increases, critically above $0 \mathrm{~V}_{\mathrm{Ag} / \mathrm{AgCl}}$ (above the reversible potential of $\mathrm{Sn}$ ).

\section{Acknowledgements}

The authors would like to thank the Ministerio de Ciencia e Innovación of the Spanish government for the financial support under the project MAT2011-22481.

\section{References}

[1] É. Martin, M. Azzi, G.A. Salishchev, J. Szpunar, Influence of microstructure and texture on the corrosion and tribocorrosion behavior of Ti-6Al-4V, Tribol. Int. 43 (2010) 918-924.

[2] M. Geetha, A.K. Singh, R. Asokamani, A.K. Gogia, Ti based biomaterials, the ultimate choice for orthopaedic implants - A review, Prog. Mater. Sci. 54 (2009) $397-425$.

[3] M. Long, H.J. Rack, Titanium alloys in total joint replacement - a materials science perspective, Biomaterials. 19 (1998) 1621-1639.

[4] M. Niinomi, D. Kuroda, K. Fukunaga, M. Morinaga, Y. Kato, T. Yashiro, et al., Corrosion wear fracture of new $\beta$ type biomedical titanium alloys, Mater. Sci. Eng. A. 263 (1999) 193-199.

[5] D. Kuroda, M. Niinomi, M. Morinaga, Y. Kato, T. Yashiro, Design and mechanical properties of new $\beta$ type titanium alloys for implant materials, Mater. Sci. Eng. A. 243 (1998) 244-249.

[6] N.S. More, N. Diomidis, S.N. Paul, M. Roy, S. Mischler, Tribocorrosion behavior of $\beta$ titanium alloys in physiological solutions containing synovial components, Mater. Sci. Eng. C. 31 (2011) 400-408.

[7] D. Rehder, Biological and medicinal aspects of vanadium, Inorg. Chem. Commun. 6 (2003) 604-617.

[8] O.M. Ivasishin, P.E. Markovsky, Y.V. Matviychuk, S.L. Semiatin, C.H. Ward, S. Fox, A comparative study of the mechanical properties of high-strength $\beta$ titanium alloys, J. Alloys Compd. 457 (2008) 296-309.

[9] E.B. Taddei, V.A.R. Henriques, C.R.M. Silva, C.A.A. Cairo, Production of new titanium alloy for orthopedic implants, Mater. Sci. Eng. C. 24 (2004) 683-687.

[10] I. Milošev, M. Metikoš-Huković, H.-H. Strehblow, Passive film on orthopaedic TiAlV alloy formed in physiological solution investigated by X-ray photoelectron spectroscopy, Biomaterials. 21 (2000) 2103-2113. 
[11] Y.F. Zheng, B.L. Wang, J.G. Wang, C. Li, L.C. Zhao, Corrosion behaviour of $\mathrm{Ti}-\mathrm{Nb}-\mathrm{Sn}$ shape memory alloys in different simulated body solutions, Mater. Sci. Eng. A. 438-440 (2006) 891-895.

[12] K. Miura, N. Yamada, S. Hanada, T.-K. Jung, E. Itoi, The bone tissue compatibility of a new Ti-Nb-Sn alloy with a low Young's modulus, Acta Biomater. 7 (2011) 2320-2326.

[13] M. Abdel-Hady Gepreel, M. Niinomi, Biocompatibility of Ti-alloys for longterm implantation, J. Mech. Behav. Biomed. Mater. 20 (2013) 407-415.

[14] S. Yu, Z. Yu, G. Wang, J. Han, X. Ma, M.S. Dargusch, Biocompatibility and osteoconduction of active porous calcium-phosphate films on a novel $\mathrm{Ti}-3 \mathrm{Zr}-$ 2Sn-3Mo-25Nb biomedical alloy, Colloids Surfaces B Biointerfaces. 85 (2011) $103-115$.

[15] B. Liu, Y.F. Zheng, Effects of alloying elements (Mn, Co, Al, W, Sn, B, C and S) on biodegradability and in vitro biocompatibility of pure iron, Acta Biomater. 7 (2011) 1407-1420.

[16] X. Wang, Y. Chen, L. Xu, Z. Liu, K.-D. Woo, Effects of Sn content on the microstructure, mechanical properties and biocompatibility of $\mathrm{Ti}-\mathrm{Nb}-$ $\mathrm{Sn}$ /hydroxyapatite biocomposites synthesized by powder metallurgy, Mater. Des. 49 (2013) 511-519.

[17] E.S.N. Lopes, R. Cremasco, Alessandra Contieri, R. Caram, Effects of Aging Heat Treatment on the Microstructure of Ti-Nb and Ti-Nb-Sn Alloys Employed as Biomaterials, Adv. Mater. Res. 324 (2011) 61-64.

[18] F. Devesa, S. Rial, V. Amigó, Processing and Characterization of $\beta$-Ti Alloys by Means of Powder Metallurgy Processing and Blender Elemental, Mater. Sci. Forum. 727-728 (2012) 61-66.

[19] E.S.N. Lopes, A. Cremasco, C.R.M. Afonso, R. Caram, Effects of double aging heat treatment on the microstructure, Vickers hardness and elastic modulus of Ti-Nb alloys, Mater. Charact. 62 (2011) 673-680.

[20] M.M. Dewidar, J.K. Lim, Properties of solid core and porous surface Ti-6Al-4V implants manufactured by powder metallurgy, J. Alloys Compd. 454 (2008) 442446.

[21] Y.J. Jo, C.M. Lee, H.S. Jang, N.S. Lee, J.-H. Suk, W.H. Lee, Mechanical properties of fully porous and porous-surfaced Ti-6Al-4V implants fabricated by electro-discharge-sintering, J. Mater. Process. Technol. 194 (2007) 121-125.

[22] V. Barranco, M.L. Escudero, M.C. García-Alonso, Influence of the microstructure and topography on the barrier properties of oxide scales generated on blasted Ti6Al4V surfaces, Acta Biomater. 7 (2011) 2716-2725. 
[23] S.L. de Assis, S. Wolynec, I. Costa, Corrosion characterization of titanium alloys by electrochemical techniques, Electrochim. Acta. 51 (2006) 1815-1819.

[24] B.A. Kolachev, A.A. Il'in, D. V Ryndenkov, Structural diagrams of titanium alloys in the "molybdenum equivalent - aluminum equivalent" coordinates, Russ. Metall. (1997) 118-128.

[25] Y. Yulan, W. Weiqi, L. Fengli, L. Weiqing, Z. Yongqiang, The effect of aluminum equivalent and molybdenum equivalent on the mechanical properties of high strength and high toughness titanium alloys, Mater. Sci. Forum. 618619 (2009) 169-172.

[26] J.K. Fan, J.S. Li, H.C. Kou, K. Hua, B. Tang, The Interrelationship of Fracture Toughness and Microstructure in a New Near $\beta$ Titanium Alloy Ti-7Mo-3Nb3Cr-3Al, Mater. Charact. (n.d.).

[27] J. Fan, H. Kou, M. Lai, B. Tang, H. Chang, J. Li, High Temperature Discontinuous Yielding in a New Near $\beta$ Titanium Alloy Ti-7333, Rare Met. Mater. Eng. 43 (2014) 808-812.

[28] S. Guo, B. Chen, Q. Meng, R. Zhao, X. Zhao, Peculiar aging response of near $\beta$ $\mathrm{Ti}-25 \mathrm{Nb}-2 \mathrm{Mo}-4 \mathrm{Sn}$ alloy for biomedical applications, Prog. Nat. Sci. Mater. Int. 23 (2013) 1-6.

[29] G.T. Aleixo, E.S.N. Lopes, R. Contieri, A. Cremasco, C.R.M. Afonso, R. Caram, Effects of cooling rate and $\mathrm{Sn}$ addition on the microstructure of Ti-Nb-Sn alloys, Solid State Phenom. 172-174 (2011) 190-195.

[30] J.E.G. González, J.C. Mirza-Rosca, Study of the corrosion behavior of titanium and some of its alloys for biomedical and dental implant applications, J. Electroanal. Chem. 471 (1999) 109-115.

[31] G.J. Brug, A.L.G. van den Eeden, M. Sluyters-Rehbach, J.H. Sluyters, The analysis of electrode impedances complicated by the presence of a constant phase element, J. Electroanal. Chem. Interfacial Electrochem. 176 (1984) 275-295.

[32] B.L. Wang, Y.F. Zheng, L.C. Zhao, Effects of Sn content on the microstructure, phase constitution and shape memory effect of $\mathrm{Ti}-\mathrm{Nb}-\mathrm{Sn}$ alloys, Mater. Sci. Eng. A. 486 (2008) 146-151.

[33] C.V. Vidal, A.I. Muñoz, C.-O.A. Olsson, S. Mischler, Passivation of a CoCrMo PVD Alloy with Biomedical Composition under Simulated Physiological Conditions Studied by EQCM and XPS, J. Electrochem. Soc. . 159 (2012) C233C243.

[34] A. Dalmau, V.G. Pina, F. Devesa, V. Amigó, A. Igual Muñoz, Influence of fabrication process on electrochemical and surface properties of Ti-6Al$4 \& \# x a 0 ; \mathrm{V}$ alloy for medical applications, Electrochim. Acta. (n.d.). 
[35] W. Wang, F. Mohammadi, A. Alfantazi, Corrosion behaviour of niobium in phosphate buffered saline solutions with different concentrations of bovine serum albumin, Corros. Sci. 57 (2012) 11-21.

[36] M. Metikoš-Huković, A. Kwokal, J. Piljac, The influence of niobium and vanadium on passivity of titanium-based implants in physiological solution, Biomaterials. 24 (2003) 3765-3775.

[37] I. Milošev, T. Kosec, H.-H. Strehblow, XPS and EIS study of the passive film formed on orthopaedic Ti-6Al-7Nb alloy in Hank's physiological solution, Electrochim. Acta. 53 (2008) 3547-3558.

[38] I. Milošev, G. Žerjav, J.M. Calderon Moreno, M. Popa, Electrochemical properties, chemical composition and thickness of passive film formed on novel Ti-20Nb-10Zr-5Ta alloy, Electrochim. Acta. 99 (2013) 176-189. 